\title{
THE CONTENT OF COUMARIN IN THE COMMERCIAL SAMPLES OF CINNAMON BARK AND CINNAMON-CONTAINING DIETARY SUPPLEMENTS AVAILABLE ON THE SERBIAN MARKET
}

\author{
M. Drobac*, J. ArseniJević and N. Kovačević \\ Department of Pharmacognosy, University of Belgrade-Faculty of Pharmacy, Vojvode Stepe 450, \\ 11221 Belgrade. Serbia
}

(Received: 2 December 2019; accepted: 16 April 2020)

\begin{abstract}
Cinnamon bark is used worldwide due to its characteristic flavour and medicinal properties. Ceylon cinnamon or "true" cinnamon bark refers to the dried inner bark of the shoots of Cinnamomum verum J. Presl, originated from Sri Lanka. The bark of some other species of this genus, Cinnamomum cassia Blume (Chinese cinnamon), C. burmanni (Nees \& T. Nees) Blume (Indonesian cinnamon), and C. loureiroi Nees (Saigon cinnamon) are also marketed and sold as cinnamon. They are characterised by a significantly higher amount of coumarin compared to Ceylon cinnamon bark. Since coumarin may be potentially hepatotoxic, the aim of this study was to determine coumarin level in commercial samples of cinnamon bark and in cinnamon-containing dietary supplements present on the Serbian market. HPLC analysis showed lowest coumarin content in Ceylon cinnamon bark samples $(0.08-0.15$ $\left.\mathrm{mg} \mathrm{g}^{-1}\right)$, whereas other samples contained a significantly higher amounts of coumarin $\left(1.38-5.80 \mathrm{mg} \mathrm{g}^{-1}\right)$. Cinnamon based dietary supplements contained $0.007-1.19 \mathrm{mg}$ coumarin/tablet. The obtained results indicate that the majority of commercial samples of cinnamon bark on the Serbian market do not originate from the Ceylon cinnamon but from other species of this genus, and that consumed amount of certain products should be taken into account since the tolerable daily intake of coumarin is limited.
\end{abstract}

Keywords: Cinnamomum verum, "Cassia" barks, coumarin, HPLC analysis

Cinnamon bark, also known as cinnamon, is well-known since antiquity due to its characteristic flavour and medicinal properties. It is used as a spice as well as in phytotherapy for symptomatic treatment of mild diarrhoea and mild spasmodic gastrointestinal complaints including bloating and flatulence (TEUSCHER et al., 2006; EMA, 2011). Cinnamon bark and its essential oil are applied as flavouring agents in the food, beverage, and pharmaceutical industries (AvUla et al., 2015).

Different species of the genus Cinnamon are commonly referred to as 'cinnamon'. Ceylon cinnamon or "true" cinnamon refers to the dried inner bark of the shoots of Cinnamomum verum J. Presl (syn. C. zeylanicum Blume) (Lauraceae), originated from Sri Lanka (Avula et al., 2015; PH. Eur., 2017). The barks of some other species of this genus, Cinnamomum cassia Blume (syn. C. aromaticum Nees) (Chinese cinnamon), C. burmanni (Nees \& T. Nees) Blume (Indonesian cinnamon), and C. loureiroi Nees (Saigon cinnamon), commonly known as "Cassia" barks, are also marketed and sold as cinnamon (LuNGARINI et al., 2008; WANG et al., 2013; Avula et al., 2015).

Ceylon cinnamon ("true" cinnamon) bark and "Cassia" barks can be distinguished by some variations in outer appearance (colour, shape, and thickness) when available in sticks, but for the average consumer it is not possible to distinguish between those two types of bark

\footnotetext{
* To whom correspondence should be addressed.

E-mail: milica.drobac@pharmacy.bg.ac.rs
} 
when they are powdered (Teuscher et al., 2006; WoeHrLin et al., 2010). Regarding their chemical composition, the most important difference is the coumarin content, which is significantly higher in "Cassia" barks than in Ceylon cinnamon bark (Miller et al., 1995; Avula et al., 2015).

Coumarin (benzo- $\alpha$-pyrone) is a secondary plant metabolite, found in many plants such as Melilotus officinalis L. and other species of the genus Melilotus, Dipteryx odorata (Aubl.) Willd. (tonka bean), Asperula odorata L., Cinanmomum cassia Blume, Cinnamomum burmanni (Nees \& T. Nees) Blume, etc. Due to its specific smell, which is sweet and fresh, reminiscent of freshly-mown hay, synthetic coumarin was widely used as a flavouring agent for food and beverages, until the first toxicological concerns were raised in the 1950s (SPROLL et al., 2008). Hepatotoxicity and carcinogenicity of coumarin at high doses and during prolonged exposure have been observed in animal studies. Experimental animals were also found to be more susceptible to the occurrence of toxic liver damage than humans, which is explained by the different metabolic pathways of coumarin. However, hepatotoxic metabolites may occur in some individuals (with CYP2A6 gene polymorphism, some liver diseases, chronic lymphedema), hence coumarin cannot be considered completely safe. More recent studies showed that coumarin is not a genotoxic carcinogen, so that a certain limited daily intake may be considered acceptable (EFSA, 2004; AвRAHAM et al., 2010). In that context, tolerable daily intake (TDI) of $0.1 \mathrm{mg} / \mathrm{kg}$ of coumarin per body weight/day was established by the European Food Safety Authority (EFSA, 2004) and the German Federal Institute for Risk Assessment (BFR, 2006).

Chinese, Indonesian, and Saigon cinnamon barks are cheaper, more widely marketed, and more commonly used as a spice than the Ceylon cinnamon bark. In recent years, they have been replacing the "true" cinnamon on the markets of Europe, as well as in the USA and Canada (Senanayake \& WiJeseKera, 2004; Lungarini et al., 2008; WANG et al., 2013). In most cases, the type and origin of cinnamon is not indicated on the label of the spice product (Woehrlin et al., 2010; Blahoví \& SvobodÁ, 2012). Considering that coumarin is present in much higher concentrations in the "Cassia" barks (Chinese, Indonesian, and Saigon cinnamon), high exposure to these products may be unfavourable from a safety point of view.

A number of techniques have been used for the determination of coumarin in cinnamon samples, alone or along with other compounds. Less specific and/or poorly selective methods such as titrimetric, spectrophotometric, or fluorescent analyses (LozHKIN \& SAKANYAN, 2006) are mainly replaced with chromatographic techniques. Suitable method performance was observed using thin-layer chromatography (Poole et al., 1995), HPLC (SPRoll et al., 2008; Woehrlin et al., 2010; Blahová \& Svobodá, 2012), GC-MS (Miller et al., 1995), and, more recently, with LC-MS (WANG et al., 2013; ANANTHAKRISHNAN et al., 2018). Nevertheless, HPLC methods are widely used because of their simplicity and reliability.

In this framework, the aim of this study was to determine the coumarin content in cinnamon bark samples, as well as in cinnamon-containing dietary supplements available in Serbia using a HPLC method.

\section{Materials and methods}

\subsection{Samples}

Sixteen commercial samples of cinnamon bark (B1-B16) (Table 1) were purchased from supermarkets and health food stores, and two cinnamon-containing dietary supplements (S1 and S2) (Table 2) were purchased from pharmacies in Serbia. 
Among the samples of cinnamon bark, 12 samples were powdered bark and 4 samples were in sticks. Dietary supplements were in the form of tablets.

Three samples of cinnamon bark (B14, B15, and B16), purchased from specialised health food stores, originated from Sri Lanka, and they were specified as Ceylon cinnamon ("true" cinnamon). On the packaging of other commercial samples of cinnamon bark, botanical origin (i.e. Cinnamomum species) was not indicated, with the exception of one sample (B2), which was specified as the bark of $C$. burmanni. The country of origin of most samples was Indonesia, except for the sample B8 that came from China (Table 1). Neither dietary products contained information on botanical origin of cinnamon bark.

\subsection{Sample extraction}

Five grams of the bark samples (powder or previously pulverised sticks) were sonicated in 20 $\mathrm{ml}$ of $80 \%(\mathrm{v} / \mathrm{v}) \mathrm{MeOH}$ and filtered to a $50 \mathrm{ml}$ volumetric flask. The procedure was repeated, filtrates were combined, and the final volume was adjusted to $50 \mathrm{ml}$.

Ten tablets of each dietary supplement were pulverised with mortar and pestle, adequate amounts were weighted ( $6.7 \mathrm{~g}$ for sample S1 and $6.2 \mathrm{~g}$ for sample S2) and extracted in the same manner as bark samples. Fifty millilitres of obtained filtrate was evaporated to dryness under reduced pressure (Rotavapor RII, Büchi) and redissolved in $5 \mathrm{ml}$ of $80 \%$ (v/v) MeOH. Prior to injection, extracts were filtered through a $0.45 \mu \mathrm{m}$ syringe filter (Captiva, Agilent Technologies).

\subsection{HPLC analysis}

HPLC analysis was performed on an Agilent 1100 HPLC system with diode-array detection under the following conditions: Zorbax Eclipse XDB-C18 analytical column $(250 \times 4.6 \mathrm{~mm}$; particle size $5 \mu \mathrm{m}$ ), flow rate $0.8 \mathrm{ml} \mathrm{min}^{-1}$, temperature $25^{\circ} \mathrm{C}$, injection volume $20 \mu \mathrm{l}$. Gradient elution was applied with binary mobile phase consisting of solvent A, $0.03 \%$ phosphoric acid, and solvent B, $10 \%$ of A in acetonitrile: initial $30 \%$ of B, rising to $50 \%$ in 15 min, $15-20$ min rising to $80 \%$ of $\mathrm{B}$, and returning to initial conditions till $25 \mathrm{~min}$. The chromatograms were recorded at $275 \mathrm{~nm}$.

\subsection{Quantification of coumarin}

External calibration method was validated in accordance with published guidelines (Thompson et al., 2002; ICH, 2005; FDA, 2018) and applied for the quantification of coumarin. Stock standard solution was prepared by dissolving $100 \mathrm{mg}$ of coumarin standard (Serva, Germany) in $80 \%$ methanol and adjusting the final volume to $100 \mathrm{ml}\left(1.0 \mathrm{mg} \mathrm{ml}^{-1}\right)$. Seven dilutions of coumarin with concentrations ranging from $0.005-0.5000 \mathrm{mg} \mathrm{ml}^{-1}$ were prepared and analysed by HPLC under the same conditions used for extracts. Standard solutions were injected three times and results were used to calculate regression line $\left(y=105507 x+29.778, r^{2}=0.9997\right)$. Linearity was assessed by lack of fit test ( $F$ calc $=1.87$, $\mathrm{Ftab}=2.96, \mathrm{P}=0.05)$. The repeatability of analysis was assessed from ten measurements of the same sample (sample B6) $(\mathrm{RSD}=3.98 \%)$. LOD $\left(0.002 \mathrm{mg} \mathrm{ml}^{-1}\right)$ was estimated by visual inspection of chromatograms of the standard solution and calculation of signal-to-noise ratio $(\mathrm{S} / \mathrm{N}>3)$. LOQ was determined as the lowest concentration of the standard used for the calibration curve $\left(0.005 \mathrm{mg} \mathrm{ml}^{-1}\right)$ as RSD of repeated injections was $<20 \%$. Recovery experiments were carried out using standard solutions at two concentration levels 
(0.01 mg ml$~^{-1}$ and $0.05 \mathrm{mg} \mathrm{ml}^{-1}$ ), resulting in recovery values of $99.8 \%$ and $99.6 \%$, respectively.

For cinnamon bark samples, the coumarin content obtained from calibration curve in $\mathrm{mg} \mathrm{ml}^{-1}$ was calculated per $\mathrm{g}$ of sample and expressed as $\mathrm{mg} \mathrm{g}^{-1}$. For cinnamon-containing dietary supplements, the results are expressed in $\mathrm{mg}$ of coumarin/tablet and in $\mathrm{mg}$ of coumarin/g of cinnamon bark. The results are expressed as mean \pm standard deviation (SD) from three repeated analyses.

\section{Results and discussion}

\subsection{Coumarin content in commercial samples of cinnamon bark}

The coumarin content in the commercially available cinnamon bark samples on the Serbian market is reported in Table 1. Coumarin was present in all investigated samples. As expected, the lowest content of coumarin was determined in Ceylon cinnamon bark samples that originated from Sri Lanka: $0.08 \mathrm{mg} \mathrm{g}^{-1}$ in sample B14, $0.14 \mathrm{mg} \mathrm{g}^{-1}$ in sample B16, and 0.15 $\mathrm{mg} \mathrm{g}^{-1}$ in sample B15. This is in accordance with previous findings on low coumarin content in the Ceylon cinnamon bark: in commercial bark samples from the USA it ranged from $0.007-0.09 \mathrm{mg} \mathrm{g}^{-1}$ (WANG et al., 2013) and in those from Germany it was $<$ LOD (limit of detection) to $0.19 \mathrm{mg} \mathrm{g}^{-1}$ (Miller et al., 1995) and from $<$ LOD to $0.486 \mathrm{mg} \mathrm{g}^{-1}$ (WoeHrLIN et al., 2010), whereas authentic samples of $C$. verum barks, originated from plantations in South India contained $0.0123-0.143 \mathrm{mg} \mathrm{g}^{-1}$ of coumarin (ANANTHAKRISHNAN et al., 2018). The other 13 currently tested samples contained significantly higher amounts of coumarin ranging between 1.38 and $5.80 \mathrm{mg} \mathrm{g}^{-1}$. Coumarin contents in these samples are consistent with previous results obtained for commercial samples of Indonesian (2.14-9.30 $\left.\mathrm{mg} \mathrm{g}^{-1}\right)$ and Saigon cinnamon barks (1.06-6.97 $\mathrm{mg} \mathrm{g}^{-1}$ ) (WANG et al., 2013). Similarly to the currently analysed samples, the samples of cinnamon bark present on the markets of several EU states contained significant amounts of coumarin. Powdered cinnamon barks designated as "Cassia" cinnamon from the German market contained $2.88-4.82 \mathrm{mg} \mathrm{g}^{-1}$ of coumarin (SPROLL et al., 2008). Commercial cinnamon samples available in the Czech Republic contained 2.65-7.02 $\mathrm{mg} \mathrm{g}^{-1}$ (BLahoví \& Svobodí, 2012) and those from Italy up to $4.45 \mathrm{mg} \mathrm{g}^{-1}$ of coumarin (LUNGARINI et al., 2008).

The obtained results indicate that the majority of commercial cinnamon bark samples on the Serbian market do not originate from the Ceylon cinnamon but from other species of this genus, most probably C. burmanni (Indonesian cinnamon). The situation is similar in other countries in Europe, as well as in the USA and India, where samples of "Cassia" barks also prevail among the cinnamon samples on the market (LuNGARINI et al., 2008; WANG et al., 2013; ANANTHAKRISHNAN et al., 2018).

Considering that coumarin is present in much higher concentrations in the Indonesian, Chinese, and Saigon cinnamon barks, a high intake of these products, especially by sensitive individuals, can pose a potential health risk.

Since TDI of coumarin established by EFSA is $0.1 \mathrm{mg} \mathrm{kg}^{-1}$ body weight per day (EFSA, 2004), for person of average body weight $(70 \mathrm{~kg}$ ) daily amount of coumarin should not exceed $7 \mathrm{mg}$. By consuming one teaspoon $(5 \mathrm{~g})$ of the majority of the investigated samples (B1, B2, B3, B4, B5, B7, B8, B9, B10, and B12) other than Ceylon cinnamon barks (B14, $\mathrm{B} 15$, and B16), the tolerable daily intake of coumarin would be exceeded. Because of the high coumarin content, certain samples should not be administered in quantities of more than 
$1.2 \mathrm{~g}$ (sample B1) and $1.6 \mathrm{~g}$ (samples B12 and B5) per day (for a person of $70 \mathrm{~kg} \mathrm{TM}$ ). According to the recommendation of the German BfR (BfR, 2006), "Cassia" barks should be used moderately, and consumers who often use large amounts of cinnamon should opt for a Ceylon cinnamon bark because of the significantly smaller amount of coumarin.

Table 1. Coumarin content in cinnamon bark commercial samples

\begin{tabular}{llc}
\hline Product No. & Product description/country of origin & $\begin{array}{c}\text { Coumarin content } \\
\left(\mathrm{mg} \mathrm{g}^{-1} \text { sample }\right) \\
\mathrm{Mean}^{\mathrm{S}} \mathrm{SD}\end{array}$ \\
\hline B1 & Powder/Indonesia & $5.80 \pm 0.04$ \\
B2 & Powder/Indonesia & $2.46 \pm 0.38$ \\
B3 & Powder/Indonesia & $2.79 \pm 0.55$ \\
B4 & Powder/Indonesia & $2.13 \pm 0.03$ \\
B5 & Powder/Indonesia & $4.35 \pm 0.02$ \\
B6 & Powder/Indonesia & $1.39 \pm 0.15$ \\
B7 & Powder/Indonesia & $2.84 \pm 0.17$ \\
B8 & Powder/Indonesia & $1.91 \pm 0.07$ \\
B9 & Powder/Indonesia & $2.87 \pm 0.02$ \\
B10 & Powder/Indonesia & $1.59 \pm 0.05$ \\
B11 & Sticks/Indonesia & $1.39 \pm 0.20$ \\
B12 & Sticks/Indonesia & $4.48 \pm 0.18$ \\
B13 & Sticks/China & $1.38 \pm 0.20$ \\
B14 & Sticks/Sri Lanka & $0.08 \pm 0.02$ \\
B15 & Powder/Sri Lanka & $0.15 \pm 0.01$ \\
B16 & Powder/Sri Lanka & $0.14 \pm 0.04$ \\
\hline & &
\end{tabular}

\subsection{Coumarin content in commercial dietary supplements containing cinnamon bark}

Two dietary supplements containing cinnamon bark available in pharmacies in Serbia were also analysed for coumarin content. The botanical source of cinnamon bark that was used for production was not indicated on the label of the product.

Cinnamon based dietary supplements contained $0.007 \mathrm{mg}$ coumarin/tablet (sample S1) and $1.19 \mathrm{mg}$ coumarin/tablet (sample S2) (Table 2). Since the analysed supplements contained different quantities of cinnamon bark in one tablet, concentration of coumarin was also calculated in mg of coumarin/g of cinnamon bark (Table 2). The obtained results indicate that supplement S2 is not manufactured from Ceylon cinnamon bark, but from the bark of some other Cinamomum species, i.e. "Cassia" bark, whereas for the supplement S1, the origin of cinnamon bark cannot be reliably determined based on the coumarin content.

Table 2. Coumarin content in commercial dietary supplements containing cinnamon bark

\begin{tabular}{lccc}
\hline Product & Product description (Content in 1 tablet) & \multicolumn{2}{c}{ Coumarin content } \\
\cline { 3 - 4 } No. & & $\begin{array}{c}\text { mg/tablet } \\
\text { Mean } \pm \text { SD }\end{array}$ & $\mathrm{mg} \mathrm{g}^{-1}$ of cinnamon bark \\
\hline S1 & $100 \mathrm{mg}$ of powdered cinnamon bark & $0.007 \pm 0.0007$ & 0.07 \\
S2 & $360 \mathrm{mg}$ of powdered cinnamon bark & $1.19 \pm 0.01$ & 3.19 \\
\hline
\end{tabular}


Bearing in mind that a TDI of coumarin is $0.1 \mathrm{mg} \mathrm{kg}^{-1}$, by taking 3 tablets of sample $\mathrm{S} 1$, which is the recommended daily dose given in the leaflet of the dietary supplement, the tolerable daily intake (for a person of average body weight of $70 \mathrm{~kg}$ ) will not be exceeded. However, recommended daily dose for sample S2 is 3-6 tablets, and if sample S2 is taken at the maximum daily dose ( 6 tablets), TDI of coumarin will be exceeded (for a person of body weight of $70 \mathrm{~kg}$ ).

\section{Conclusions}

The results of the present study revealed that most samples of cinnamon bark on the Serbian market had high coumarin contents, indicating that they do not originate from the Ceylon cinnamon (Cinnamomum verum) but from other Cinnamomum species. On the other hand, HPLC analysis showed low coumarin contents in the samples labelled as Ceylon cinnamon that are purchased from specialised healthy food shops. In addition, it is shown that coumarin TDI may be exceeded by consuming a number of the studied cinnamon bark samples, as well as by taking higher doses of a particular cinnamon-containing dietary supplement. Bearing in mind that the large amounts of coumarin may be potentially hepatotoxic, and that the TDI of coumarin is established, the consumed amount of certain products should be considered. In this regard, the obtained results suggest that the botanical origin of the cinnamon bark should be indicated; also that the quality control of cinnamon-based products should comprise coumarin quantification and that the content of coumarin should be stated on the product label.

This work was supported by the Ministry of Education, Science and Technological Development of the Republic of Serbia under Grant No. 173021.

\section{References}

Abraham, K., Wöhrlin, F., Lindtner, O., Heinemeyer, G. \& Lampen, A. (2010): Toxicology and risk assessment of coumarin: focus on human data. Mol. Nutr. Food Res., 54, 228-239.

Ananthakrishnan, R., Chandra, P., Kumar, B. \& Rameshkumar, K.B. (2018): Quantification of coumarin and related phenolics in cinnamon samples from south India using UHPLC-ESI-QqQLIT-MS/MS method. Int. J. Food Prop., 21, 50-57.

Avula, B., Smillie, T.J., Wang, Y.H., Zweigenbaum, J. \& Khan, I.A. (2015): Authentication of true cinnamon (Cinnamon verum) utilising direct analysis in real time (DART)-QToF-MS. Food Addit. Contam. A., 32, 1-8.

BFR (2006): Consumers, who eat a lot of cinnamon, currently have an overly high exposure to coumarin. (Federal Institute for Risk Assessment) BfR Health Assessment No. 043/2006.

Blahoví, J. \& Svobodá, Z. (2012): Assessment of coumarin levels in ground cinnamon available in the Czech retail market. Sci. World J., 2012, 1-4.

EFSA (2004): Opinion of the Scientific Panel on food additives, flavourings, processing aids and materials in contacts with food (AFC) on a request from the Commission related to coumarin. EFSA J., 104, 1-36.

EMA (2011): (European Medicines Agency), Committee on Herbal Medicinal Products (HMPC). Community herbal monograph on Cinnamomum verum J.S. Presl, cortex. EMA/HMPC/246774/2009.

FDA (2018): Guidance for Industry: Bioanalytical method validation. (U.S. Department of Health and Human Services Food and Drug Administration) Silver Spring, Maryland.

ICH (2005): ICH harmonized tripartite guideline: Validation of analytical procedures: text and methodology Q2(R1). (International conference of harmonization of technical requirements for registration of pharmaceuticals for human use) 
Lozhrin, A.V. \& Sakanyan, E.I. (2006): Natural coumarins: Methods of isolation and analysis. Pharm. Chem. J., 40, 337-346.

Lungarini, S., Aureli, F. \& Coni, E. (2008): Coumarin and cinnamaldehyde in cinnamon marketed in Italy: A natural chemical hazard? Food Addit. Contam., 25, 1297-1305.

Miller, K.G., Poole, C.F. \& Chichila, T.M.P. (1995): Solvent-assisted supercritical fluid extraction for the isolation of semivolatile flavor compounds from the cinnamons of commerce and their separation by series-coupled column gas chromatography. J. High Res. Chromatog., 18, 461-471.

PH. Eur (2017): European Pharmacopoeia $9^{\text {th }}$ ed., Council of Europe, Strasbourg, France, pp. 1317-1318.

Poole, S.K., Kiridena, W., Miller, K.G. \& Poole, C.F. (1995): Planar chromatographic methods for determination of the quality of spices and flavors as exemplified by cinnamon and vanilla. J. Planar Chromat., 8, 257-268.

SenANAYAKe, U.M. \& WiJesekera, R.O.B. (2004): Chemistry of cinnamon and cassia. -in: RAVINDRAN, P.N., NIRMAL Babu, K. \& Shylaja, M. (Eds) Cinnamon and Cassia: the genus Cinnamomum. CRC Press, Boca Raton, pp. $81-120$.

Sproll, C., Ruge, W., Andlauer, C., Godelmann, R. \& Lachenmeier, D.W. (2008): HPlC analysis and safety assessment of coumarin in foods. Food Chem., 109, 462-469.

Teuscher, E., Bauermann, U. \& Werner, M. (2006): Medicinal spices. Medpharm GmbH Scientific Publishers, Stuttgart, Germany, pp. 118-124.

Thompson, M., Ellison, S.L.R. \& Wood, R. (2002): Harmonized guidelines for single-laboratory validation of method of analyses (IUPAC Technical Report). Pure Appl. Chem., 74(5), 835-855.

Wang, Y.H., Avula, B., Dhammika Nanayakkara, N.P., ZhaO, J. \& Khan, I.A. (2013): Cassia cinnamon as a source of coumarin in cinnamon-flavored food and food supplements in the United States. J. Agr. Food Chem., 61, $4470-4476$.

Woehrlin, F., Fry, H., Abraham, K. \& Preiss-Weigert A. (2010): Quantification of flavoring constituents in cinnamon: high variation of coumarin in cassia bark from the German retail market and in authentic samples from Indonesia. J. Agr. Food Chem., 58, 10568-10575. 